\title{
Chrysobalanaceae: traditional uses, phytochemistry and pharmacology
}

\author{
Evanilson Alves Feitosa, ${ }^{1}$ Haroudo Satiro Xavier, ${ }^{1}$ Karina Perrelli \\ Randau $^{*}, 1$
}

Laboratório de Farmacognosia, Universidade Federal de Pernambuco, Brazil.

\begin{abstract}
Chrysobalanaceae is a family composed of seventeen genera and about 525 species. In Africa and South America some species have popular indications for various diseases such as malaria, epilepsy, diarrhea, inflammations and diabetes. Despite presenting several indications of popular use, there are few studies confirming the activities of these species. In the course of evaluating the potential for future studies, the present work is a literature survey on databases of the botanical, chemical, biological and ethnopharmacological data on Chrysobalanaceae species published since the first studies that occurred in the 60's until the present day.
\end{abstract}
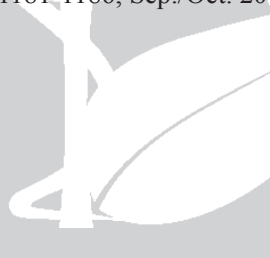

Review

Received 16 Jan 2012

Accepted 25 Apr 2012

Available online 14 Jun 2012

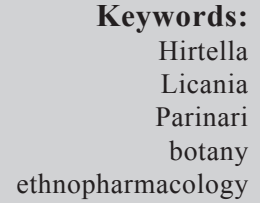

ISSN 0102-695X http://dx.doi.org/10.1590/S0102 $695 \times 2012005000080$

\section{Introduction}

Chrysobalanaceae was first described by the botanist Robert Brown in his study "Observations, systematical and geographical, on the herbarium collected by Professor Christian Smith, in the vicinity of the Congo, during the expedition to explore that river, under the command of Captain Tuckey, in the year 1816" (Salisbury, 1818). It is a family composed of seventeen genera and about 525 species. These are woody plants, shrubs and trees found in tropical and subtropical regions, mainly in the New World tropics (Yakandawala et al., 2010). The wood is of little advantage due to high rate of silica, but several species have edible fruits (Prance, 1988).

\section{Material and Methods}

An extensive search through books and original articles was carried out in this work. The search was performed accessing SciFinder, ScienceDirect, Web of Science, Scielo and NAPRALERT databases, updated to February 2012. The keywords used for this review were Chrysobalanaceae, Licania, Parinari and the names of all other Chrysobalanaceae genus. More than $90 \%$ of the references obtained were later consulted.

\section{Botany (morphology and microscopy)}

The Chrysobalanaceae plants have entire leaves, hard, provision of alternate, distichous, with stipules.
Small flowers usually greenish-white, cyclic, zigomorphic, diclamides, with a developed receptacle, sepals and petals free, general pentamers, androecium consists of two stamens to many free or more or less welded together; superomedial ovary, bi to tricarpellate, unilocular, usually with only one ovule and fruit usually drupaceous. In the Brazilian Cerrado and in the Amazonian forests trees from the species of the genus Licania can be found. Some of them are known as "oiticica", and they are oil-producing. The Cerrado species usually present a very twisted trunk. In Northeastern Brazil, species of Licania and Moquilea are known as "oiti". Other genera of the Amazon region produces the fruit called "pajurá" (Parinarium). Also in the Amazon, species of Couepia produce a type of nut known as "castanha-de-cutia" (Joly, 1998). Again in Northeast Brazil, many are used as forage potential: Chrysobalanus icaco, Couepia impressa, Couepia rufa, Couepia uiti, Licania parviflora, Licania salzmannii and Licania tomentosa. In Pernambuco's Atlantic Jungle region, they are used as fodder: Couepia impressa and Couepia rufa and on the coast Chrysobalanus icaco and Licania tomentosa (Tabarelli \& Silva, 2002).

Metcalfe \& Chalk (1988) describes anatomical features of some species of Chrysobalanaceae. The petiole has a closed cylinder of xylem and phloem, and two small adaxial vascular strands, with variations occurring among genera and species of a single genus. The leaves show paracytic stomata (sometimes only on the abaxial surface) and epidermis with mucilaginous walls, with papillose on abaxial surface; hypoderm is 
present in some species. It has a ramified, peltate, stellate or glandular hairs. Mesophyll has predominantly a dorsiventral traversed by lignified cells, like fiber. Veins with vascular bundles surrounded by sclerenchymatous fibers. Vessel cells with simple perforations without spiral thickening, uni-triseriate bands of apotracheal parenchyma in heterogeneous rays, and pits bordered in fibers. Silica crystal, isolated or clustered, is present into membranes, into epidermis cells, into idioblasts surrounding leaf veins and in the mesophyll. Secretory cavities are also found in some genera. A continuous or discontinuous ring of sclerenchyma encircles the vascular cylinder, characterizing the pericycle, and cells with U-thickening in transversal section. The main vascular bundle shows variations related to xylem and phloem arrangement.

\section{Ethnopharmacology}

In folk medicine, Chrysobalanaceae species are used for various purposes. Among those in popular use, the species of the genus Licania show the largest number of biological activities, and are vastly used in Venezuela as an anti-inflammatory (Pittier, 1978). Most of them are cultivated because of its edible fruits (Toledo et al., 1982).

In Northeastern Brazil, Licania species has its leaves used to treat diabetes (Agra et al., 2007), stomach aches (Albuquerque et al., 2007), diarrhea and dysentery (Cartaxo et al., 2010). The stem bark of Parinari excelsa, which is widespread in Senegal (Ndiaye et al., 2008), is also used to treat diabetes; and also leaves of Hirtella racemosa, that is commonly known in the northern Brazil as "ajirú-do-mato" (Coelho-Ferreira, 2009).

Chrysobalanus icaco, also known as "abajeru", is a medium sized shrub native of the American coast. It is used in folk medicine for the treatment of leucorrhoea, bleeding and chronic diarrhea, and is also known for its diuretic, hypoglycemic and antiangiogenic effects (Costa, 1977; Paulo et al., 2000; Vargas-Simon et al., 1997). In Northern Brazil, its root is used to treat diabetes (CoelhoFerreira, 2009).

Parinari species, like P. curatellifolia and $P$. excelsa, are traditionally used in Africa as a remedy for dysentery, epilepsy, malaria, toothache and venereal diseases (Uys et al., 2002; Arnold \& Gulumian, 1984). The leave of $P$. curatellifolia is indicated to treat stomachaches in Southern Uganda (Ssegawa \& Kasenene, 2007). The stem bark of $P$. excels $a$ is used in Guinea to treat infectious diseases (Magassouba et al., 2010). In West Africa, its stem bark is popularly known as anthelmintic, and its fruit is used to treat diarrhea (Diehl et al., 2004). In Tanzania it is used as an antiseptic and to treat malaria (Kamuhabwa et al., 2000). P. polyandra is also used to treat malaria in Ghana (Asase et al, 2005).
Maranthes floribunda bark is used in West Africa to treat diarrhea and dysentery (Koné et al., 2004), Atuna racemosa is used to treat pregnancy nausea in Polynesia (Ostraff et al., 2000), and in Latin America Licania arborea is used as an antifungal (Svetaz et al., 2010). In Senegal, a cigarette is prepared from the stem bark of Neocarya macrophylla used as a remedy for snake bite (Mohagheghzadeh et al., 2006).

The ethnopharmacological uses of these species reveal that they present a significant number of indications in South America and Africa, where they are distributed. Usually. the popular knowledge can guide the search for medicinal plants, which occasionally results in the discovery of molecules with biological activity (Maciel et al., 2002). Therefore, species of Licania and Parinari can be studied for antiinflammatory activity, diabetes and malaria.

\section{Phyto-constituents}

There are few studies that address the chemical composition of species Chrysobalanaceae beyond genres Licania and Parinari. Note that there are no studies with other genera of the family as Hirtella, Dactyladenia, Exellodendron or Grangeria.

Early phytochemical studies occurred in the 60 's and described the presence of aglycone flavonoids in species of Rosaceae, including two taxa of Chrysobalanaceae: Chrysobalanus icaco and Licania rigida, where was identified the myricetin (Chaffaud \& Emberger, 1960).

Later, the investigation of 31 species of Parinari in 1985 presented that they showed a predominance of flavonoids glycosides based on myricetin (1), quercetin (2), and kaempferol (3) (Coradin et al., 1985). Other phytochemicals studies of Parinari species led to the isolation and identification of flavonoids with fatty acids and their glycosides (Chisholm \& Hopkins, 1966; Coradin et al., 1985). The molecules identified in Chrysobalanaceae are shown in the Table 1.

Phytochemical studies with the genus Licania shown similarities with other Chrysobalanaceae, resulting in the isolation and characterization of two majority classes of compounds: flavonoids and triterpene metabolites (Castilho et al., 2005). Isocarthamidin and 4-hydroxybenzoic acid were isolated by the powdered stems of $P$. anamense (Werawattanachai \& Kaewamatawong, 2010). Of $P$. curatellifolia, diterpenes with molecular core ent-kaurene derivative of 15oxozoapatlin (4) were isolated and presented cytotoxic activity (Lee et al., 1996). In other species, $P$. campestris, six diterpenes kaurane were also isolated (Braca et al., 2005). 


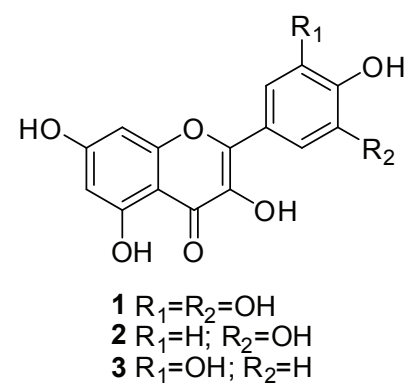

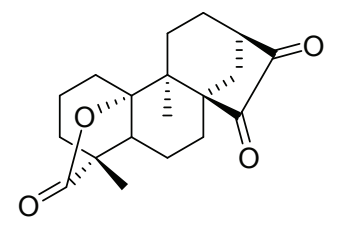

4

The study of the phytochemical composition of the other genera in the family can contribute to the characterization of the major constituents in Chrysobalanaceae.

\section{Biological activities}

There are studies that show the antihyperglycemic property of some species of Chrysobalanaceae, as Chrysobalanus icaco (Presta \& Pereira, 1987) and $P$. excelsa, confirming its use in traditional medicine (Ndiaye et al., 2008).

Cytotoxic activity is observed in the pomolic acid of Chrysobalanus icaco. Betulinic and oleanolic acid of Licania tomentosa, show ability to inhibit the growth and induce apoptosis in the cell line erythroleukemia (K562), and also to prevent proliferation of Lucena 1, a derived vincristine-resistant from K562 (Fernandes et al., 2003). The root extract of L. michauxii has cytotoxicity against cultured human hepatoma (Hep G2) and colon

Table 1. Molecules identified in Chrysobalanaceae species.

\begin{tabular}{|c|c|}
\hline Specie & Molecules \\
\hline Licania apetala & $\begin{array}{l}\text { kaempferol-3-rutinoside, myricetin-3-rhamnoside, myricetin-4'-rhamnoside, quercetin-3- } \\
\text { rhamnoside, quercetin-3-arabinoside, quercetin-3-galactoside, quercetin 3-glucoside, rutin, } \\
\text { taxifolin-3-rhamnoside }\end{array}$ \\
\hline Licania arianeae & $\begin{array}{l}\text { acid 3-O-[6'-O-4-hidroxybenzoyl]- } \beta \text {-D-galactopyranosyl-ursa-12-en-28-óico, acid flavone-6- } \\
\text { sulphonic, 4'-O-methyl-5,7-diidroxy-flavone-6-sulphonic. }\end{array}$ \\
\hline Licania densiflora & $\begin{array}{l}\text { myricetin (1), myricetin-3-rhamnoside, myricetin-3-glucoside, myricetin-3-galactoside, } \\
\text { myricetin-4'-methoxy-3-rhamnoside, myricetin-3',5'-dimethylether-3-rhamnoside, myricetin-3' } \\
\text { methylether-3-galactoside, myricetin-3'-methylether-3-glucoside, myricetin-3',5'-dimethylether } \\
\text { 3-O-glucoside, myricetin-3-O- } \alpha \text {-L-(2''-O- } \alpha \text {-L-rhamnopyranosyl)-rhamnopyranoside-3',4'- } \\
\text { dimethylmyricetin-3- } O \text { - } \beta \text {-D-glucopyranoside, quercetin (2), quercetin-3-rhamnoside, } \\
\text { quercetin-3-glucoside, narigenin-8-hydroxy-4'-methyl ether, catechin }\end{array}$ \\
\hline $\begin{array}{l}\text { Licania } \\
\text { heteromorpha }\end{array}$ & $\begin{array}{l}\text { myricetin-3-galactoside, myricetin-4'-methoxy-3-rhamnoside, myricetin-3,4'-di- } O \text { - } \alpha \text {-L- } \\
\text { rhamnopyranoside, myricetin-4'-methyl ether-3- } O-\beta \text {-D-galactopyranoside, myricetin-4'- } \\
\text { methoxy-3-galactoside, myricetin-4'-methoxy-3-glucoside, myricetin-7-methyl ether-3,4'-di- } O \text { - } \\
\alpha \text {-L-rhamnopyranoside, betulinic acid, alphitolic acid }\end{array}$ \\
\hline Licania licaniaeflora & $\begin{array}{l}\text { kaempferol-3-(2"-xylosyl)-rhamnoside, kaempferol-3-rhamnoside, myricetin-3-arabinoside, } \\
\text { myricetin-3-galactoside, dihidromyricetin-3-rhamnoside, quercetin-3-rhamnoside, quercetin- } \\
\text { 3-arabinoside, 8-hydroxy-narigenin, taxifolin-3-rhamnoside, oleanolic acid, maslinic acid, } \\
\text { oleanolic acid 3-O-arabinoside, betulinic acid, arjunetin, tomentic acid glucosyl ester, pomolic } \\
\text { acid, olean-12-en-2 } \alpha, 3 \beta \text {-diol }\end{array}$ \\
\hline
\end{tabular}

Licania pittieri quercetin (2), quercetin-3-rhamnoside, quercetin-3-arabinoside, quercetin-3-galactoside, quercetin 3-glucoside, catechin, epicathechin, ursolic acid, oleanolic acid

(Carvalho \& Da Costa, 2009)

(Braca et al., 1999a; Braca, 2001b)

(Braca et al., 1999b; Braca et al., 1999c)

(Braca et al., 2002, Braca et al., 2001a, Bilia et al., 1996a)

(Bilia et al., 1996a; Mendez et al., 1995)

Licania pyrifolia kaempferol (3), kaempferol-3-rhamnoside, kaempferol-3-arabinoside, kaempferol-3-(2"'-xylosil) rhamnoside, hypoletin, 8-hydroxy-eriodictyol, 8-hydroxy-narigenin, myricetin (1), myricetin3-rhamnoside, myricetin-3-(2"'-xylosyl)rhamnoside, quercetin (2), quercetin-3-rhamnoside, quercetin-3-arabinoside, quercetin-3-(2"'-xylosyl)rhamnoside

Licania tomentosa betulinic acid, licanolide, palmitoeic acid, oleanolic acid, stigmasterol, sitosterol, lupeol, tomentic acid, ursolic acid

Licania carii myricetin-3-rutinoside, myricetin-3-glucoside, myricetin-3-(2"'-xylosyl)rhamnoside, quercetin3-(2"'-xylosyl)rhamnoside, quercetin-3-galactoside, quercetin 3-glucoside, rutin, $2 \alpha$-hydroxy ursolic acid, betulinic acid, maslinic acid.

Parinari campestris $\quad$ kaempferol-3-rutinoside, 15-oxozoapatlin-13 $\alpha$-yl-10' $\alpha, 16$ ' $\alpha$-dihydroxy-9' $\alpha$-methyl-20'norkauran-19'-oic acid $\gamma$-lactone-17'-oate, 13-hydroxy-15-oxozoapatlin, $10 \alpha, 13 \alpha, 16 \alpha, 17$ tetrahydroxy-9 $\alpha$-methyl-15-oxo-20-nor-kauran-19-oic acid $\gamma$-lactone, $2 \alpha, 10 \alpha, 13 \alpha, 16 \alpha, 17$ pentahydroxy-9 $\alpha$-methyl-15-oxo-20-nor-kauran-19-oic acid $(19,10)$-lactone, $3 \alpha, 10 \alpha, 13 \alpha, 16 \alpha, 17$-pentahydroxy-9 $\alpha$-methyl-15-oxo-20-nor-kauran-19-oic acid $\gamma$-lactone, $1 \beta, 16 \alpha, 17$-trihydroxy-ent-kaurane.

Parinari 15-oxozoapatlin (4), 13-methoxy-15-oxozoapatlin, 13-hydroxy-15-oxozoapatlin.

(Lee et al., 1996) curatellifolia

Chrysobalanus icaco pomolic acid.

(Fernandes et al., 2003) 
carcinoma (Caco-2) (Badisa et al., 2000). Ent-kaurane diterpenes isolated from the root of $P$. curattellifolia, show cytotoxicity in vitro against several cancer cell lines (Lee et al., 1996). P. capensis has moderate cytotoxicity against cell lines of lung cancer, renal cancer and melanoma (Fouche et al., 2008).

The presence of cytotoxicity may be indicative of anticancer action of these compounds, further studies are needed to assess the mechanism of action responsible for cytotoxicity and in vivo evaluation of these molecules and extracts. The presence of cytotoxic activity of kaurane diterpenes is discussed in many studies in different species (He et al., 2009; HuesoFalcón et al., 2010; Lin et al., 2012);

Diterpenes found in P. capensis have antifungal (Garo et al., 1997) and antimalarial activity, but have high toxicity (Uys et al., 2002). The hexane extract of Couepia grandiflora has antibacterial activity against Pseudomonas aeruginosa and the ethanolic extract against Staphylococcus aureus and Pseudomonas aeruginosa (Zuque et al., 2004).

Diterpenes of Chrysobalanus icaco have antiHIV activity (Gustafson et al., 1991), and aqueous extract of leaves have a potent genotoxic effect (Ferreira-Machado et al., 2004).

Other activities of the genus Licania are described. Quercetin flavonoids obtained from sheets of L. licaniaeflora and L. heteromorpha exhibit antioxidant activity (Braca et al., 2001a; Montoro et al., 2005). Licania carii, L. pittieri and L. pyrifolia are toxic against Biomphalaria glabrata Say, a mollusk involved in the reproductive cycle of Schistosoma mansoni Sambon (Bilia et al., 2000). The extract of $L$. tomentosa has the ability to inhibit herpes simplex virus type I acyclovirresistant (ACVr-HSV1) and interfere with the initial process of infection in non-cytotoxic concentrations (Miranda et al., 2002).

The fruits of Atuna racemosa presents antiinflammatory activity by inhibiting the biosynthesis of prostaglandins (Dunstan et al., 1997). Although Licania species have popular indication as anti-inflamatory, there are few studies to support this use.

\section{Conclusion}

Chrysobalanaceae species have indications in the traditional medicine and treatments for various diseases such as malaria, epilepsy, diarrhea, bleeding, venereal disease and diabetes. But there are few studies, both phytochemical and pharmacological, which express with larger therapeutic potential of these species and chemicals.

Chrysobalanus icaco and Parinari excelsa have results that express their potential on treating diabetes, but other species with popular indications such as Hirtella racemosa, lack of pharmacological studies. Licania tomentosa and Chrysobalanus icaco have activity in vitro in the treatment of multidrug-resistant erythroleukemia, confirming the value of natural products in search of new active substances. We should also watch for the need of developing countries to research alternative therapies and substances candidates for drugs to fight diseases called "neglected". Species such as Parinari excelsa and P. curatellifolia present popular indication in the treatment of malaria, and there are no studies to prove this statement, while Licania carii, L. pittieri and L. pyrifolia need more studies to prove his action in the fight against schistosomiasis.

Moreover, it appears that the molecules isolated by Chrysobalanaceae, mostly, are flavonoids and terpenoids. In a particular way, flavonoids and terpenes being mentioned in most species of Licania and kaurene diterpene in species of Parinari.

Chrysobalanaceae still presents itself as an unexplored source for the isolation and characterization of new active substances. Thus, new researches can open new paths in the discovery of molecules with therapeutic action and drug discovery.

\section{References}

Agra MF, França PF, Barbosa-Filho JM 2007. Synopsis of the plants known as medicinal and poisonous in Northeast of Brazil. Rev Bras Farmacogn 17: 114-140.

Albuquerque UP, Monteiro JM, Ramos MA, Amorim ELC 2007. Medicinal and magic plants from a public market in northeastern Brazil. J Ethnopharmacol 110: 76-91.

Arnold HJ, Gulumian MJ 1984. Pharmacopoeia of traditional medicine in Venda. $J$ Ethnopharmacol 12: 35-74.

Asase A, Oteng-Yeboah AA, Odamtten GT, Simmondsb MSJ 2005. Ethnobotanical study of some Ghanaian antimalarial plants. $J$ Ethnopharmacol 99: 273-279.

Badisa BB, Chaundhuri SK, Pilarinou E, Rutkoski NJ, Hare J, Levenson CW 2000. Licania michauxii Prance root extract induces hsp 70 mRNA and necrotic cell death in cultured human hepatoma and colon carcinoma cell lines. Cancer Lett 149: 61-68.

Bilia AR, Ciampi L, Mendez J, Morelli I 1996a. Phytochemical investigations of Licania genus. Flavonoids from Licania pyrifolia. Pharm Acta Helv 71: 199-204.

Bilia AR, Mendez J, Morelli I 1996b. Phytochemical investigations of Licania genus. Flavonoids and triterpenoids from Licania carii. Pharm Act Helv 71: 191-197.

Bilia AR, Braca A, Mendez J, Morelli I 2000. Molluscicidal and piscicidal activities of Venezuelan Chrysobalanaceae plants. Life Sci 66: 53-59.

Braca A, Bilia AR, Mendez J, Morelli I 1999a. Three flavonoids from Licania densiflora. Phytochemistry 
51: 1125-1128.

Braca A, De Tomassi N, Mendez J, Morelli I 1999b. Flavonoids and triterpenoids from Licania heteromorpha (Chrysobalanaceae). Biochem Syst Ecol 27: 527-530.

Braca A, De Tommasi N, Mendez J, Morelli I, Pizza C 1999c. Three flavonoids from Licania heteromorpha. Phytochemistry 51: 1121-1124.

Braca A, Sortino C, Mendez J, Morelli I 2001a. Trierpenes from Licania licaniaeflora. Fitoterapia 72: 585-587.

Braca A, Bilia A R, Mendez J, Morelli I 2001b. Myricetin glycosides from Licania densiflora. Fitoterapia 72: $182-185$.

Braca A, Luna D, Mendez J, Morelli I 2002. Flavonoids from Licania apetala and Licania licaniaeflora (Chrysobalanaceae). Biochem Syst Ecol 30: 271-273.

Braca A, Abdel-Razik AF, Mendez J, Morelli I 2005. A new kaurane diterpene dimer from Parinari campestris. Fitoterapia 76: 614-619.

Cartaxo SL, Souza MMA, Albuquerque UP 2010. Medicinal plants with bioprospecting potential used in semi-arid northeastern Brazil. J Ethnopharmacol 131: 326-342.

Carvalho MG, Da Costa PM 2009. Outros constituintes isolados de Licania arianeae (Chrysobalanaceae). Brazil J Pharmacogn 19(1B): 290-293.

Castilho RO, Oliveira RR, Kaplan MAC 2005. Licanolide, a new triterpene lactone from Licania tomentosa. Fitoterapia 76: 562-566.

Castilho RO, Kaplan MAC 2008. Constituintes químicos de Licania tomentosa Benth. (Chrysobalanaceae). Quim Nova 31: 66-69.

Chaffaud M, Emberger L 1960. Traité de Botanique Systematique Vol. II. Paris: Masson, p. 1338-1340.

Chisholm MJ, Hopkins, CY 1966. Kamloenic acid and other conjugated fatty acids in certain seed oils. $\mathrm{J} \mathrm{Am} \mathrm{Oil}$ Chem Soc 43: 390-392.

Coelho-Ferreira M 2009. Medicinal knowledge and plant utilization in an Amazonian coastal community of Marudá, Pará State (Brazil). J Ethnopharmacol 126: 159-175.

Coradin L, Giannasi DE, Prance AT 1985. Chemosystematic studies in the Chrysobalanaceae. Flavonoids in Parinari. Britton 37: 169-178.

Costa OA 1977. Plantas hipoglicemiantes brasileiras II. Brasil: Leandra p 63-75.

Diehl MS, Atindehou KK, T'er'e H, Betschart B 2004. Prospect for anthelminthic plants in the Ivory Coast using ethnobotanical criteria. J Ethnopharmacol 95: 277-284.

Dunstan CA, Noreen Y, Serrano G, Cox PA, Pereira P, Bohlin L 1997. Evaluation of some Samoan and Peruvian medicinal plants by prostaglandin biosynthesis and rate ear oedema assays. $J$ Ethnopharmacol 57: 35-36.

Fernandes J, Castilho RO, Costa MR, Wagner-Souza K, Kaplan MAC, Gattass CR 2003. Pentacyclic triterpenes from Chrysobalanaceae species: cytotoxicity on multidrug resistant and sensitive leukemia cell lines. Cancer Lett 190: 165-169.

Ferreira-Machado SC, Rodrigues MP, Nunes APM, Dantas FJS, De Matos JCP, Silva CR, Moura EG, Bezerra RJAC, Caldeira-de-Araujo A 2004. Genotoxic potentiality of aqueous extract prepared from Chrysobalanus icaco L. leaves. Toxicol Lett 151: 481-487.

Fouche G, Cragg GM, Pillay P, Kolesnikova N, Maharaj VJ, Senabe J 2008. In vitro anticancer screening of South African plants. J Ethnopharmacol 119: 455-461.

Garo E, Maillard M, Hostettmann K, Stoeckli-Evvans H, Mavi S 1997. Absolute configuration of a diterpene lactone from Parinari capensis. Helv Chim Acta 80: 538-544.

Gustafson KR, Munro MHG, Cardellina JH, MC Malon JB, Gulakowshi RJ, Cragg GM, Cox PB, Linda SJ 1991. HIV inhibitory natural products. 3. Diterpenes from Homalantus acuminatus and Chrysobalanus icaco. Tetrahedron 47: 4547-4554.

Hueso-Falcón I, Girón N, Velasco P, Amaro-Luis JM, Ravelo AG, Heras B, Hortelano S, Estevez-Braun A 2010. Synthesis and induction of apoptosis signaling pathway of ent-kaurane derivatives. Bioorg. Med Chem 18: 1724-1735.

He F, Xiao WL, Pu JX, Wu YL, Zhang HB, Li XN, Zhao Y, Yang LB, Chen GQ, Sun HD 2009. Cytotoxic ent-kaurane diterpenoids from Isodon sinuolata. Phytochemistry 70: 1462-1466.

Joly AB 1998. Botânica: introdução à taxonomia vegetal. Brasil: IBEP.

Kamuhabwa A, Nshimo C, de Witte P 2000. Cytotoxicity of some medicinal plant extracts used in Tanzanian traditional medicine. J Ethnopharmacol 70: 143-149.

Koné WM, Atindehou KK, Terreaux C, Hostettmann K, Traoré D, Dosso M 2004. Traditional medicine in North Côte-d'Ivoire: screening of 50 medicinal plants for antibacterial activity. $J$ Ethnopharmacol 93: 4349.

Lee I, Shamon L, Chai H, Chagwedera TE, Besterman JM, Farnsworth NR, Cordell GA, Pezzuto JM, Kinghorn AD 1996. Cell-cycle specific cytotoxicity mediated by rearranged ent-kaurene diterpenoids isolated from Parinari curatellifolia. Chem-Biol Interact 99: 193204.

Lin L, Gao Q, Cui C, Zhao H, Fu L, Chen L, Yang B, Luo $\mathrm{W}$, Zhao M 2012. Isolation and identification of ent-kaurane-type diterpenoids from Rabdosia serra (Maxim.) Hara leaf and their inhibitory activities against HepG-2, MCF-7, and HL-60 cell lines. Food Chem 131: 1009-1014.

Maciel MAM, Pinto AC, Veiga Jr VF, Grynberg NF, Echevarria A 2002. Plantas medicinais: a necessidade de estudos multidisciplinares. Quim Nova 25. no.3.

Magassouba FB, Diallo A, Kouyaté M, Mara F, Mara O, Bangoura O, Camara A, Traoré S, Diallo AK, Zaoro 
M, Lamah K, Diallo S, Camara G, Traoré S, Kéita A, Camara MK, Barry R, Kéita S, Oularé K, Barry MS, Donzo M, Camara K, Toté K, Vanden Berghe D, Totté J, Pieters L, Vlietinck AJ, Baldé AM 2010. Corrigendum to "Ethnobotanical survey and antibacterial activity of some plants used in Guinean traditional medicine". J Ethnopharmocol 114: 44-53.

Mendez J, Bilia AR, Morelli I 1995. Phytochemical investigations of Licania genus. Flavonoids and triterpenoids from Licania pittieri. Pharm Acta Helv 70: 223-226.

Metcalfe CR, Chalk L 1988. Anatomy of the dicotyledons: systematic anatomy of the leaf and stem vol 1. Oxford: Clarendon Press.

Miranda MMFS, Gonçalves JLS, Romanos MTV, Silva FP, Pinto L, Silva MH, Ejzemberg R, Granja LFZ, Wigg MD 2002. Anti-herpes simplex virus effect of a seed extract from the tropical plant Licania tomentosa (Benth.) Fritsch (Chrysobalanaceae). Phytomedicine 9: 641-645.

Mohagheghzadeh A, Faridi P, Shams-Ardakani M, Ghasemi Y 2006. Medicinal smokes. J Ethnopharmacol 108: 161-184.

Montoro P, Braca A, Pizza C, De Tommasi N 2005. Structureantioxidant activity relationships of flavonoids isolated from different plant species. Food Chem 92: 349-355.

Ndiaye M, Diatta W, Sy AN, Dièye AM, Faye B, Bassène E 2008. Antidiabetic properties of aqueous barks extract of Parinari excelsa in alloxan-induced diabetic rats. Fitoterapia 79: 267-270.

Ostraff M, Anitoni K, Nicholson A, Booth GM 2000. Traditional Tongan cures for morning sickness and their mutagenic: toxicological evaluations. $J$ Ethnopharmacol 71: 201-209.

Paulo SA, Balassiano IT, Silva NH, Castilho RO, Kaplan MAC, Cabral MC, Carvalho MGC 2000. Chrysobalanus icaco L. Extract for antiangiogenic potential observation. Internat J Mol Med 5: 667669.

Pittier H 1978. Manual de las plantas usuales de Venezuela. Caracas: Editorial Fundación Eugenio Mendoza, p 579

Prance GT 1988. Flora do Estado de Goiás. Goiânia: Ed. da Universidade Federal de Goiás.

Presta GA, Pereira NA 1987. Atividade do abagerú (Crysobalanus icaco Lin, Crysobalanaceae) em modelos experimentais para o estudo de plantas hipoglicemiantes. Rev Bras Farm 68: 91-101.

Salisbury R 1818. "[Review of] Narrative of an expedition to explore the River Zaire, usually called the Congo, in South Africa, in 1816, under the direction of Captain J. H. Tuckey, R. N". Month Rev 86: 113-129, 292-305.

Ssegawa P, Kasenene JM 2007. Medicinal plant diversity and uses in the Sango bay area, Southern Uganda. $J$ Ethnopharmacol 113: 521-540.

Svetaz L, Zuljan F, Derita M, Petenatti E, Tamayo G, Cáceres A, Filho VC, Giménez A, Pinzón R, Zacchino SA, Gupta M 2010. Value of the ethnomedical information for the discovery of plants with antifungal properties. A survey among seven Latin American countries. $J$ Ethnopharmacol 127: 137-158.

Tabarelli M, Silva JMC 2002. Diagnóstico da Biodiversidade de Pernambuco. Recife: Secretaria de Ciência, Tecnologia e Meio Ambiente, Editora Massangana.

Toledo CL, Kbitzki K, Prance GH 1982. Flora de Venezuela vol IV. Caracas: Ediciones Fundacion Educacion Ambiental p 332-406.

Uys ACU, Malan SF, van Dyck S, van Zyl RL 2002. Antimalarial compounds from Parinari capensis. Bioorg Medic Chem Lett 12: 2167.

Vargas-Simon G, Arellano-Ostoa G, Garcia-Villanueva E 1997. Propagación por estacas com hojas de icaco (Chrysobalanus icaco) y anatomía del enraizamento. Proced Internat Soc Trop Horticul 41: 264-269.

Werawattanachai N, Kaewamatawong R 2010. Chemical constituents from Parinari anamense. Biochem Syst Ecol 38: 836-838.

Yakandawala D, Morton CM, Prance GT 2010. Phylogenetic relationships of the Chrysobalanaceae inferred from chloroplast, nuclear, and morphological data. Ann Missouri Bot Gard 97: 259-281.

Zuque ALF, Watanabe ES, Ferreira AMT, Arruda ALA, Resende UM, Bueno NR, Castilho RO 2004. Avaliação das atividades antioxidante, antimicrobiana e citotóxica de Couepia grandiflora Benth. (Chrysobalanaceae). Rev Bras Farmacogn 14: 129-136.

\section{*Correspondence}

Karina Perrelli Randau

Laboratório de Farmacognosia, Universidade Federal de Pernambuco

Cidade Universitária, 50740-521 Recife-PE, Brazil

karina.prandau@ufpe.br

Tel.: +558130764774 